\title{
Dihydroxyacetone Synthase: a Special Transketolase for Formaldehyde Fixation from the Methylotrophic Yeast Candida boidinii CBS 5777
}

\author{
By M. J. WAITES AND J. R. QUAYLE* \\ Department of Microbiology, The University, Sheffield S10 2TN, U.K.
}

(Received 13 July 1982)

\begin{abstract}
The transketolase synthesized by Candida boidinii CBS 5777 during growth on non- $\mathrm{C}_{1}$ substrates has been purified and shown to have a molecular weight of approximately 135000 and to consist of two subunits of approximate molecular weight 68000 . The enzyme is active with xylulose 5phosphate as glycolyl donor and ribose 5-phosphate as acceptor; under the conditions of assay formaldehyde was inactive as acceptor. Candida boidinii CBS 5777 also synthesizes a second transketolase during growth on methanol. This enzyme, which is unstable, has been purified to homogeneity. It has a wide substrate specificity towards glycolyl donors and acceptors; formaldehyde is a good acceptor and in terms of its physiological role during growth on methanol the enzyme can be described as a dihydroxyacetone synthase. This enzyme has a molecular weight of 105000-110000, with two subunits of molecular weight $62000-67000$. Its properties have been compared with analogous enzymes purified elsewhere from methanolgrown Candida boidinii KDl and Candida boidinii (Kloeckera sp.) 2201.
\end{abstract}

\section{INTRODUCTION}

A key step in the xylulose monophosphate (XuMP) cycle of formaldehyde fixation which operates in methylotrophic yeasts during growth on methanol is a transketolase-type reaction involving the transfer of a glycolaldehyde fragment from XuMP to formaldehyde, producing dihydroxyacetone (DHA) and glyceraldehyde 3-phosphate (Kato et al., 1979; O'Connor \& Quayle, 1980; Waites \& Quayle, 1980). During growth on methanol two transketolases are synthesized which can be separated by ion-exchange or hydroxylapatite chromatography. One is a relatively stable classical transketolase that is also found during growth on multi-carbon substrates, the other is an unstable special transketolase (DHA synthase) (O'Connor \& Quayle, 1980; Waites \& Quayle, 1980, 1981; Bystrykh et al., 1981; Kato et al., 1982). The classical transketolase shows little or no activity with formaldehyde as glycolaldehyde acceptor whereas the DHA synthases from Candida boidinii CBS 5777 and C. boidinii (Kloeckera sp.) 2201 have been shown to exhibit both classical and DHA synthase activities, i.e. they can use both aldose phosphates (such as ribose 5-phosphate) and formaldehyde as acceptors for the glycolyl group from the donor (Waites \& Quayle, 1981; Kato et al., 1982). By contrast, Bystrykh et al. (1981) have reported that the DHA synthase from Candida boidinii KD1 is more specific, with formaldehyde being the only active glycolaldehyde acceptor out of the six aldehydes and aldose phosphates tested.

In the present paper we describe the purification, substrate specificity and general properties of the DHA synthase from methanol-grown Candida boidinii CBS 5777, comparing it with transketolases in general and DHA synthases recently purified from closely related strains.

\footnotetext{
Abbreviations: DHA, dihydroxyacetone; DHAP, dihydroxyacetone phosphate; DTT, dithiothreitol; GAP, glyceraldehyde 3-phosphate; MTT, 3-(4,5-dimethylthiazolyl-2)-2,5-diphenyltetrazolium bromide; PCMB, $p$ chloromercuribenzoic acid; PES, phenazine ethosulphate; PMSF, phenylmethane sulphonyl fluoride; RiMP, ribose 5-phosphate; TEMED, $N, N, N^{\prime}, N^{\prime}$-tetramethylethylenediamine; TPP, thiamin pyrophosphate; XuMP, xylulose 5-phosphate.
} 


\section{METHODS}

Organism and growth conditions. Candida boidinii CBS 5777 was grown in shake flasks at $30^{\circ} \mathrm{C}$ in the vitaminsupplemented mineral salts medium of Van Dijken et al. (1976). Filter-sterilized methanol $(0.5 \%$, w/v) or ethanol $(0.2 \%, \mathrm{w} / \mathrm{v})$ and autoclaved glucose or xylose $(0 \cdot 2 \%, \mathrm{w} / \mathrm{v})$ were used as carbon and energy sources. For all studies, cultures were harvested in late-exponential phase by centrifugation at $6000 \mathrm{~g}$ for $20 \mathrm{~min}$.

Preparation of extracts. Cell-free extracts were prepared by ultrasonication (MSE model $150 \mathrm{~W}$ ) at $0{ }^{\circ} \mathrm{C}$ for $6 \times$ $1 \mathrm{~min}$ at $1 \mathrm{~min}$ intervals in $4 \mathrm{vol} .10 \mathrm{~mm}-\mathrm{KH}_{2} \mathrm{PO}_{4} / \mathrm{NaOH} \mathrm{pH} 7.0$ containing $0.5 \mathrm{~mm}$-TPP. For the breakage of methanol-grown cells the buffer contained the following additional compounds: $\mathrm{MgCl}_{2}, 5 \mathrm{mM}$; DTT, $1.0 \mathrm{mM}$; EDTA, $1.0 \mathrm{mM}$; PMSF, $0.024 \%(\mathrm{w} / \mathrm{v})($ Kato $e$ al., 1982); this is referred to hereafter as buffer A. Supernatants obtained following centrifugation at $38000 \mathrm{~g}$ for $20 \mathrm{~min}$ were used for all further enzyme studies.

Enzyme assays. All assays were carried out in $1 \mathrm{ml}$ total volume at $30^{\circ} \mathrm{C}$ using a Pye-Unicam SP 1800 doublebeam recording spectrophotometer.

Classical transketolase (EC 2.2.1.1) and DHA synthase were routinely assayed by the continuous methods described previously (Waites \& Quayle, 1981). The DHA synthase assay system contained glycylglycine buffer pH 7.6, $50 \mathrm{~mm} ; \mathrm{MgCl}_{2}, 2 \mathrm{~mm}$; NADH, 0.15 mM; TPP, 0.005\%(w/v); ATP, $1 \mathrm{~mm}$; triosephosphate isomerase (EC 5.3.1.1), 6 units; glycerol-3-phosphate dehydrogenase (EC 1.1 1. .8), 0-8 unit; glycerol kinase (EC 2.7.1 .30, from Candida mycoderma), 2 units; XuMP, $2.5 \mathrm{mM}$; formaldehyde, $2 \mathrm{mM}$. To study the substrate specificity for glycolaldehyde donors and acceptors the assay was slightly modified. In assays with various possible glycolaldehyde donors the acceptor was always formaldehyde; activity was measured by following only DHA production in the system described above but lacking triose phosphate isomerase. Activity with various glycolaldehyde acceptors was determined by monitoring only GAP production in the system described previously with XuMP as donor but lacking ATP and glycerol kinase.

Fructose-bisphosphate aldolase (EC 4.1.2.13) and catalase (EC 1.11.1.6) were determined by the procedures of Van Dijken et al. (1978) and Lück (1963), respectively. Lactate dehydrogenase (EC 1.1.1.27) was determined spectrophotometrically in an assay mixture containing $10 \mathrm{~mm}-\mathrm{Tris} / \mathrm{HCl}$ buffer $\mathrm{pH} 7 \cdot 5,0.15 \mathrm{~mm}-\mathrm{NADH}$ and enzyme preparation; after assessing NADH oxidase activity the assay was started by adding sodium pyruvate to a concentration of $5 \mathrm{mM}$. Malate dehydrogenase (EC 1.1.1.37) was assayed by the same method except that the assay was started by addition of oxaloacetate to $0.5 \mathrm{~mm}$ instead of sodium pyruvate.

Purification of classical transketolase and DHA synthase and determination of their molecular weights. All procedures were carried out at $0-5^{\circ} \mathrm{C}$.

Step 1. Cell-free extracts obtained from $10 \mathrm{~g}$ cell paste were applied directly to a column $(2 \times 8 \mathrm{~cm})$ of hydroxylapatite (Bio-Gel HTP) which had been equilibrated with sonication buffer, and eluted with a linear phosphate gradient (10-400 $\mathrm{mm}$ in $200 \mathrm{ml}$ sonication buffer) essentially as described previously (Waites \& Quayle, 1981). Extracts from cells grown on substrates other than methanol produced a single peak of classical transketolase activity. Those grown on methanol gave two peaks, the second also exhibited DHA synthase activity (cf. Waites \& Quayle, 1981). The peaks were concentrated by ultrafiltration using an Amicon ultrafiltration unit fitted with a PM 10 Diaflo membrane (Amicon, High Wycombe, Bucks, U.K.).

Step 2. The concentrated preparation $(2-4 \mathrm{ml})$ was applied to a Sephadex G-200 column $(70 \times 2.5 \mathrm{~cm}$; bed volume, $375 \mathrm{ml}$; void volume, $147 \mathrm{ml}$ ), which had been equilibrated with buffer $A$ and calibrated using the following molecular weight standards: ferritin (horse spleen), catalase (EC 1.11.1.6, beef liver), aldolase (EC 4.1.2.13, rabbit muscle), lactate dehydrogenase (EC 1.1.1.27, rabbit muscle), malate dehydrogenase (EC 1.1.1.37, pig heart, mitochondrial), ovalbumin (hen egg) and cytochrome $c$ (horse heart). When purification alone was required the sample was run without accompanying standards, but for an accurate molecular weight determination samples were run with standards. Proteins were eluted with buffer A at a column flow rate of $15 \mathrm{ml}$ $\mathrm{h}^{-1}$ and collected in $3 \mathrm{ml}$ fractions.

Non-equilibrium pH gradient electrophoresis (NEPHGE). The procedure used was based on the methods of O'Farrell et al. (1977). Gels $(7.5 \%$, w/v acrylamide) were prepared in glass tubes $(7 \times 0.5 \mathrm{~cm})$ from a mixture which consisted of $6.25 \mathrm{ml}$ stock acrylamide $[28.4 \%(\mathrm{w} / \mathrm{v})$ acrylamide and $1.6 \%(\mathrm{w} / \mathrm{v})$ bis-acrylamide $], 1.25 \mathrm{ml}$ stock ampholines (LKB; 40\%, w/v; pH 5-7) giving a final concentration of $2 \%(\mathrm{w} / \mathrm{v}), 35 \mu 1$ TEMED and $17.5 \mathrm{ml}$ distilled water. The mixture was degassed for $2 \mathrm{~min}$ and $50 \mu \mathrm{l}$ freshly prepared $10 \%(\mathrm{w} / \mathrm{v})$ ammonium persulphate added. The gels were poured, overlaid with distilled water and allowed to polymerize overnight. Gels were loaded into the electrophoresis apparatus which contained $0.02 \mathrm{M}-\mathrm{NaOH}$ in the lower reservoir with the cathode. The distilled water overlay was removed and samples of enzyme (40-60 $\mu \mathrm{l})$ in buffer A containing in addition $10 \%$ $(\mathrm{w} / \mathrm{v})$ glycerol, $0.8 \%(\mathrm{w} / \mathrm{v})$ ampholine $\mathrm{pH} 5-7$ and $0.2 \%(\mathrm{w} / \mathrm{v})$ ampholine $\mathrm{pH} 3-10$ were placed on to the gels. Samples were overlaid to the top of the tubes with a solution containing a mixture of $0.8 \%(\mathrm{w} / \mathrm{v})$ ampholine $\mathrm{pH} 5-7$ and $0 \cdot 2 \%(\mathrm{w} / \mathrm{v})$ ampholine $\mathrm{pH} 3-10$. The upper reservoir containing the anode was filled with $0 \cdot 01 \mathrm{M}-\mathrm{H}_{3} \mathrm{PO}_{4}$ and the gels run without prerun at $400 \mathrm{~V}$ for $3 \mathrm{~h}$ at $5^{\circ} \mathrm{C}$.

Staining of NEPHGE gels for classical transketolase and DHA synthase activities. Gels were removed from the electrophoresis tubes, placed in test tubes and quickly washed in ice-cold $20 \mathrm{~mm}$-glycylglycine buffer pH 7.6. The 
buffer was decanted off and replaced with $2.6 \mathrm{ml}$ of a solution containing glycylglycine buffer $\mathrm{pH} 7.6,50 \mathrm{~mm}$; $\mathrm{MgCl}_{2}, 2 \mathrm{mM}$; sodium arsenate, $9.5 \mathrm{mM}$; NAD, $1 \mathrm{mM} ; \mathrm{TPP}, 0.005 \%(\mathrm{w} / \mathrm{v}) ;$ MTT, $0.04 \%(\mathrm{w} / \mathrm{v}) ; \mathrm{PES}, 0.01 \%(\mathrm{w} / \mathrm{v})$; DTT, $0.5 \mathrm{~mm}$; GAP dehydrogenase (EC 1.2.1.12), 10 units $\mathrm{ml}^{-1}$, which was prepared immediately before use. The appropriate glycoaldehyde donor and acceptor substrates were added to the tubes in $0.4 \mathrm{ml}$ to give a final concentration of each of $2 \mathrm{mM}$, followed by incubation in the dark at $30^{\circ} \mathrm{C}$ for $30 \mathrm{~min}$ to $1 \mathrm{~h}$. For the detection of DHA synthase XuMP or hydroxypyruvate was used as donor with formaldehyde or glycolaldehyde as acceptor. When hydroxypyruvate was used as glycolaldehyde donor 4 units of glycerol kinase (EC 2.7.1.30), 20 units of triose phosphate isomerase and $1 \mathrm{~mm}$-ATP were also present. Classical transketolase activity was detected with $\mathrm{XuMP}$ as donor and RiMP as acceptor substrates. The DHA synthase band detected by the staining procedure was cut from the gel with a razor blade, placed in a vial with $0.5 \mathrm{ml}$ distilled water and pulverized using a glass rod. Protein was extracted overnight at $5{ }^{\circ} \mathrm{C}$; the overlying aqueous extract was then removed and stored at $-15^{\circ} \mathrm{C}$ until required.

SDS-disc-polyacrylamide gel electrophoresis. The methods used were based on those of Laemmli (1970). Separation gels $(5-10 \%$, w/v acrylamide $)$ were prepared without stacking gels in glass tubes $(7 \times 0.5 \mathrm{~cm})$. Samples were prepared in the buffer mixture of Laemmli (1970) and then held at $90{ }^{\circ} \mathrm{C}$ for $3 \mathrm{~min}$, cooled, and applied to the gels. Samples were overlaid with electrophoresis buffer and run at $5 \mathrm{~mA}$ for 3-4 h. Gels were stained with $2 \%$ $(\mathrm{w} / \mathrm{v})$ Coomassie brilliant blue $\mathrm{G} 250$ in $7 \%(\mathrm{v} / \mathrm{v})$ acetic acid for $1-2 \mathrm{~h}$, then destained in repeated changes of $7 \%$ $(\mathrm{v} / \mathrm{v})$ acetic acid containing $5 \%(\mathrm{v} / \mathrm{v})$ methanol. Molecular weight standards used were cytochrome $c$ (horse heart), trypsin inhibitor (soya bean), ovalbumin (hen egg), catalase subunit (beef liver), bovine serum albumin and RNA polymerase $\alpha, \beta$ and $\beta^{\prime}$ subunits (Escherichia coli).

Analytical methods and chemicals. Protein was determined by the Lowry method using bovine serum albumin as standard. Dextran blue, cytochrome $c$, ferritin and ovalbumin were estimated by extinction at $625 \mathrm{~nm}, 412 \mathrm{~nm}$, $230 \mathrm{~nm}$ and $280 \mathrm{~nm}$, respectively. Formaldehyde was prepared as described previously (Waites \& Quayle, 1981). Biochemicals and enzymes were mainly purchased from Boehringer except transketolase, hydroxypyruvate, ovalbumin, glycolaldehyde, XUMP, ribulose 5-phosphate, SDS, MTT, PES and TPP, which were obtained from Sigma. DHA and glyceraldehyde were supplied by BDH. Ampholines were purchased from LKB.

\section{RESULTS}

\section{Purification of DHA synthase}

Previous attempts to purify DHA synthase have been greatly hindered by its extreme instability, and efforts to stabilize it by various means have had limited success (O'Connor \& Quayle, 1980; Waites \& Quayle, 1981). Neither the supernatant from boiled cell-free extracts nor peroxisome preparations from methanol-grown cells had appreciable stabilizing effect. Recently Kato et al. (1982) reported that the DHA synthase from Candida boidinii (Kloeckera sp.) 2201 could be stabilized by using a phosphate buffer containing $\mathrm{MgCl}_{2}$, TPP, EDTA, DTT and PMSF (buffer A), and that if any one component was omitted the stabilizing effect was greatly decreased. In our earlier studies we investigated all of these compounds, individually and in various pairs, but never all together. We have now examined the effects of buffer $A$ on the thermal stability of DHA synthase in crude cell-free extracts of $C$. boidinii CBS 5777 . During incubation at $35^{\circ} \mathrm{C}$ there was an initial loss of approximately $50 \%$ of the activity. However, the remaining activity was stable for long periods at this temperature, which was a great improvement over the effect seen in the absence of the buffer A mixture (Fig. 1). The omission of individual components from buffer A was also studied (Table 1), and as Kato et al. (1982) found, the most effective stabilization was provided by the complete mixture. During our stability tests, omission of PMSF had relatively little influence, whereas stabilization was considerably lowered if any one of the other components, particularly EDTA, was removed. Thereafter buffer A was used in DHA synthase purifications where a long period (over $15 \mathrm{~h}$ ) on a Sephadex G-200 column was the final step.

The purification procedure that we used, although involving only two steps, yielded apparently electrophoretically homogeneous preparations. In extracts of methanol-grown cells DHA synthase was separated from the classical transketolase by hydroxylapatite chromatography, a method which we have used extensively (Waites \& Quayle, 1981; Lindley et al., 1981). Previously, losses of DHA synthase at this stage were often over $90 \%$, but the use of buffer A lowered this to approximately $50 \%$. The final step was Sephadex G-200 gel filtration which we used both as a purification step (Table 2) and as a means of estimating the molecular weight. 


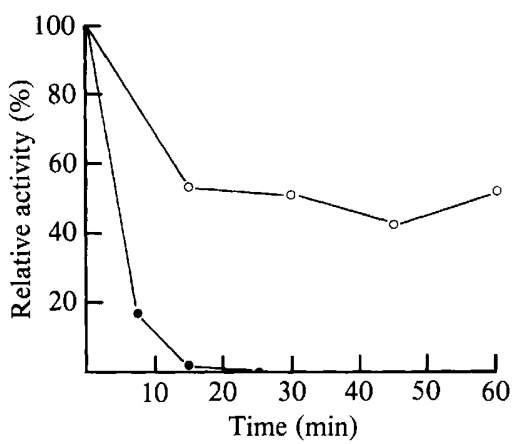

Fig. 1. Thermal stability of DHA synthase in crude cell-free extracts of methanol-grown $C$. boidinii. The extracts were prepared from 1 g cell paste sonicated in $4 \mathrm{ml} 10 \mathrm{~mm}-\mathrm{KH}_{2} \mathrm{PO}_{4} / \mathrm{NaOH}$ buffer $\mathrm{pH} 7 \cdot 0$ (O) or $4 \mathrm{ml}$ buffer $\mathrm{A}(\mathrm{O})$ (see Methods for details). Extracts were incubated at $35^{\circ} \mathrm{C}$ and samples were withdrawn at intervals and assayed for DHA synthase activity.

Table 1. Effects of the various components of buffer A on the stability of DHA synthase activity in crude extracts of methanol-grown Candida boidinii CBS 5777

Cell-free extracts of methanol-grown $C$. boidinii were prepared in $10 \mathrm{~mm}-\mathrm{KH}_{2} \mathrm{PO}_{4} / \mathrm{NaOH}$ buffer $\mathrm{pH} 7 \cdot 0$. The extract was divided into portions to which additional buffer containing various components was added to give a final protein concentration of $5 \mathrm{mg} \mathrm{ml}^{-1}$ and component concentrations as specified below. Samples of these preparations were then assayed for DHA synthase activity, incubated at $35{ }^{\circ} \mathrm{C}$ for $15 \mathrm{~min}$ and re-assayed. Relative activity is based on activity with complete buffer $\mathrm{A}$ as $100 \%$.

Incubation buffer

Complete buffer $\mathrm{A}^{*}$

$-\mathrm{MgCl}_{2}$

- TPP

- EDTA

- DTT

- PMSF

- $\mathrm{MgCl}_{2}$, TPP, EDTA, DTT, PMSF
Relative DHA synthase activity remaining after $15 \mathrm{~min}$ incubation at $35^{\circ} \mathrm{C}$
100
$63 \cdot 9$
$48 \cdot 5$
$34 \cdot 6$
$79 \cdot 2$
$96 \cdot 2$
$1 \cdot 5$

* Buffer A contained $\mathrm{MgCl}_{2}$, $5 \mathrm{mM}$; TPP, 0.5 mM; DTT, $1.0 \mathrm{mM}$; EDTA, $1.0 \mathrm{mM}$; PMSF, 0.024\% (w/v).

\section{Table 2. Purification of $D H A$ synthase from methanol-grown Candida boidinii}

The crude extract was prepared from $10 \mathrm{~g}$ cell paste suspended in $40 \mathrm{ml}$ buffer A (see Methods). This buffer was used at all stages of the purification. Values in parentheses are classical transketolase activities with XuMP and RiMP as glycolyl donor and acceptor, respectively. Activities are expressed as $\mu \mathrm{mol} \mathrm{min}^{-1}$, and specific activities as $\mu \mathrm{mol} \mathrm{min}^{-1}(\mathrm{mg} \text { protein })^{-1}$. The values given in the 'Ratio' column refer to the activity ratio of classical transketolase to DHA synthase.

\begin{tabular}{|c|c|c|c|c|c|c|c|c|}
\hline Step & $\begin{array}{c}\text { Volume } \\
\text { (ml) }\end{array}$ & & tal & & $\begin{array}{l}\text { cific } \\
\text { ivity }\end{array}$ & $\begin{array}{c}\text { Yield } \\
(\%)\end{array}$ & Purification & Ratio \\
\hline Crude extract & 45 & $56 \cdot 43$ & $(36 \cdot 18)$ & 0.204 & $(0 \cdot 131)$ & 100 & 1 & - \\
\hline $\begin{array}{l}\text { Hydroxylapatite } \\
\text { chromatography }\end{array}$ & 55 & 26.53 & $(17.68)$ & 0.443 & $(0.295)$ & $47 \cdot 0$ & $2 \cdot 2$ & 0.67 \\
\hline $\begin{array}{l}\text { Sephadex G-200 } \\
\text { chromatography }\end{array}$ & 21 & $12 \cdot 64$ & $(9 \cdot 35)$ & 0.766 & $(0.567)$ & $22 \cdot 4$ & 3.8 & 0.74 \\
\hline
\end{tabular}

During purification, the activity ratio of the classical transketolase function (RiMP as acceptor) to DHA synthase function (formaldehyde as acceptor) of DHA synthase increased slightly from 0.67 in the peak from hydroxylapatite chromatography to 0.74 in the enzyme fraction from Sephadex G-200. Nevertheless the ratio remained constant enough to indicate that a single enzyme was responsible for both activities. 


\section{Table 3. Substrate specificity of DHA synthase for glycolaldehyde acceptors}

Enzyme activity in preparations partially purified by hydroxylapatite chromatography was assayed by following the production of GAP in a continuous assay with XuMP as glycolaldehyde donor at an assay concentration of $2.5 \mathrm{~mm}$ and with an acceptor concentration of $2 \mathrm{mM}$ (see Methods for details). Apparent kinetic constants were determined using the direct linear plot method of Eisenthal \& CornishBowden (1974). Relative activity is based on activity with formaldehyde as acceptor as $100 \%$.

\section{Acceptor substrate}

Formaldehyde

Glycolaldehyde

DL-Glyceraldehyde

Acetaldehyde

D-Erythrose 4-phosphate

D-Ribose 5-phosphate

D-Ribose

D-Glucose 6-phosphate

Glutaraldehyde

Dihydroxyacetone

$\begin{array}{cc}\begin{array}{c}\text { Relative activity } \\ (\%)\end{array} & K_{\mathrm{m}}(\mathrm{mM}) \\ 100 \cdot 0 & 1 \cdot 14 \\ 141 \cdot 0 & 0 \cdot 55 \\ 60 \cdot 9 & 2 \cdot 60 \\ 46 \cdot 6 & - \\ 127 \cdot 2 & 1 \cdot 68 \\ 72 \cdot 4 & 0 \cdot 45 \\ 0 & - \\ 0 & - \\ 0 & - \\ 0 & -\end{array}$

\section{Table 4. Substrate specificity for glycolaldehyde donors of DHA synthase}

Enzyme activity in preparations partially purified by hydroxylapatite chromatography was assayed by following DHA production in a continuous assay. In each case the glycoaldehyde acceptor was formaldehyde at an assay concentration of $2 \mathrm{mM}$ and with a donor concentration of $2.5 \mathrm{~mm}$. Apparent kinetic constants were determined using the direct linear plot method of Eisenthal \& Cornish-Bowden (1974). The values in parentheses are those obtained with a preparation further purified on a column of Sephadex G-200 and free from ribulose-5-phosphate 3-epimerase (see Methods for details). Relative activity is based on activity with XuMP as donor as $100 \%$.

\begin{tabular}{lcc}
\multicolumn{1}{c}{ Donor substrate } & $\begin{array}{c}\text { Relative activity } \\
(\%)\end{array}$ & $K_{\mathrm{m}}(\mathrm{mM})$ \\
D-Xylulose 5-phosphate & 100 & $0 \cdot 72$ \\
Hydroxypyruvate & $41 \cdot 4$ & $0 \cdot 28$ \\
D-Ribulose 5-phosphate & $(0)$ & $(-)$ \\
D-Fructose 6-phosphate & $25 \cdot 2$ & 1.56 \\
D-Glucose 6-phosphate & 0 & - \\
D-Ribose 5-phosphate & 0 & -
\end{tabular}

\section{Properties of DHA synthase}

DHA synthase functioned with a range of both glycolaldehyde donor and acceptor substrates (Tables 3 and 4). Formaldehyde, glycolaldehyde and erythrose 4-phosphate appeared to be the best glycolaldehyde acceptors while glyceraldehyde, acetaldehyde and RiMP were less good. The enzyme was more specific as regards glycolaldehyde donor substrates (Table 4). Of those that we tested XuMP was the most effective, though hydroxypyruvate and fructose 6-phosphate also served in this capacity. RiMP and glucose 6-phosphate did not function as glycolaldehyde donors, nor did ribulose 5-phosphate unless ribulose-5-phosphate 3-epimerase (EC 5.1 .3 .1) was present.

DHA synthase required both TPP and $\mathrm{MgCl}_{2}$, as activity was reduced by $28.0 \%$ and $62.4 \%$, respectively, in their absence (Table 5). As with some classical transketolases, the order of addition of TPP and $\mathrm{MgCl}_{2}$ also influenced activity (Datta \& Racker, $1961 a$ ). If TPP was added to the enzyme before $\mathrm{MgCl}_{2}$, activity was decreased by $37 \cdot 1 \%$. Manganese ions ( $2 \mathrm{mM}$ ) replaced magnesium ions $(2 \mathrm{mM})$ to some extent but the same concentrations of zinc or nickel ions completely inhibited DHA synthase activity. Addition of PCMB (1 mM) also resulted in $100 \%$ inhibition. Reduced glutathione or ribose equimolar with formaldehyde ( $2 \mathrm{mM})$ produced $60 \%$ and $31.5 \%$ inhibition, respectively. Ammonium sulphate concentrations greater than $10 \mathrm{~mm}$ also inhibited DHA synthase activity; this effect was shown to be mainly due to the sulphate ion. 
Table 5. Effects of cofactors and inhibitors on the activity of DHA synthase

Enzyme activity in preparations partially purified by hydroxylapatite chromatography was assayed by monitoring GAP production in a continuous assay with XuMP as glycolaldehyde donor and formaldehyde as acceptor at assay concentrations of $2.5 \mathrm{~mm}$ and $2.0 \mathrm{mM}$, respectively. The enzyme was dissolved in $\mathrm{KH}_{2} \mathrm{PO}_{4} / \mathrm{NaOH}$ buffer (approx. $0 \cdot 2 \mathrm{M}, \mathrm{pH} 7 \cdot 0$ ). See Methods for details.

Assay system

Complete assay system

- TPP

$-\mathrm{MgCl}_{2}$

$\mathrm{Zn}^{2+}$ replacing $\mathrm{Mg}^{2+}$

$\mathrm{Ni}^{2+}$ replacing $\mathrm{Mg}^{2+}$

$\mathrm{Mn}^{2+}$ replacing $\mathrm{Mg}^{2+}$

Complete system, TPP added before $\mathrm{Mg}^{2+}$

Complete system + PCMB (1 mM)*

Complete system + GSH (2 mM)

Complete system + D-ribose (2 $\mathrm{mM})$

Complete system $+\left(\mathrm{NH}_{4}\right)_{2} \mathrm{SO}_{4}(25 \mathrm{~mm})$

Complete system $+\left(\mathrm{NH}_{4}\right)_{2} \mathrm{SO}_{4}(100 \mathrm{mM})$

Complete system $+\mathrm{NH}_{4} \mathrm{Cl}(50 \mathrm{~mm})$

\section{Relative activity}

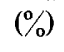

100

$72 \cdot 0$

$37 \cdot 6$

0

0

$72 \cdot 6$

62.9

0

$40 \cdot 0$

$68 \cdot 5$

$87 \cdot 5$

$56 \cdot 0$

94.0

* Assay system contained 10 -fold more linkage enzymes than the routine assay.

Table 6. Molecular weights of classical transketolase and DHA synthase from Candida boidinii

The enzymes were partially purified by hydroxylapatite chromatography and submitted to Sephadex G200 chromatography with and without protein standards. The enzymes from the Sephadex column chromatography without standards were then submitted to SDS-disc-polyacrylamide electrophoresis in order to determine subunit molecular weights. Where molecular weights were determined in duplicate, the respective individual values are recorded. The value in parentheses is for the estimated subunit molecular weight of DHA synthase purified by non-equilibrium $\mathrm{pH}$ gradient electrophoresis, located on the gel by a specific activity stain, extracted and submitted to SDS-disc-polyacrylamide electrophoresis. See Methods for details.

$\begin{array}{ccc}\text { Enzyme } & \text { Molecular weight } & \begin{array}{c}\text { Subunit } \\ \text { molecular weight }\end{array} \\ \begin{array}{c}\text { Classical transketolase } \\ \text { Methanol-grown }\end{array} & 142500 & 2 \times 68000 \\ \begin{array}{l}\text { Ethanol-grown } \\ \text { Xylose-grown }\end{array} & 130000 & - \\ \begin{array}{c}\text { DHA synthase } \\ \text { Methanol-grown }\end{array} & 132000 & - \\ & 105000, & 2 \times 64000, \\ & 110000 & 2 \times 67000 \\ & & (2 \times 62500)\end{array}$

\section{Molecular weight determinations}

The molecular weights of classical transketolases from methanol-, ethanol- and xylose-grown and DHA synthase from methanol-grown C. boidinii CBS 5777 were determined by Sephadex G-200 chromatography. The classical transketolases from cells grown on each of the three above substrates gave similar results of approximately 135000 , whereas DHA synthase was somewhat smaller at approximately 107500 (Table 6). Following gel filtration, samples of the peaks of classical transketolase and DHA synthase of methanol-grown cells were submitted to SDSpolyacrylamide gel electrophoresis. Single protein bands were obtained for each preparation and the subunit sizes were estimated to be approximately 65500 (Fig. 2) and 68000 for DHA synthase and classical transketolase, respectively, thus indicating that both native enzymes are probably composed of two identical subunits.

DHA synthase was also purified by non-equilibrium $\mathrm{pH}$ gradient electrophoresis. The appropriate band was identified on the basis of its being the only one which appeared in an 
DHA Mol.wt synthase standards

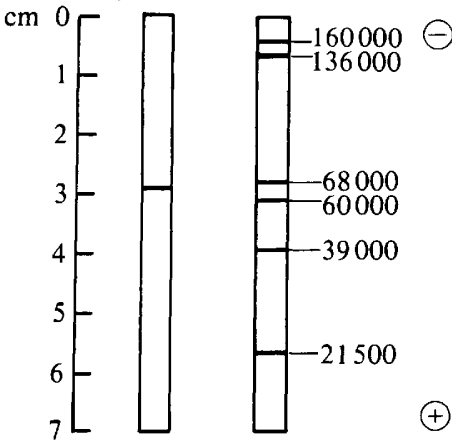

Fig. 2. SDS-disc-polyacrylamide gel electrophoresis of purified DHA synthase from methanol-grown C. boidinii. A sample of DHA synthase eluted from a Sephadex G-200 column was added to a dissociation buffer mixture, heated at $90{ }^{\circ} \mathrm{C}$ for $3 \mathrm{~min}$, cooled, and $30-80 \mu \mathrm{l}$ applied to the top of a $7.5 \%$ $(\mathrm{w} / \mathrm{v})$ polyacrylamide gel $(7 \times 0.5 \mathrm{~cm})$ containing $0.1 \%$ SDS. Gels were run at $5 \mathrm{~mA}$ for $3 \mathrm{~h}$ and stained with Coomassie brilliant blue. See Methods for details.

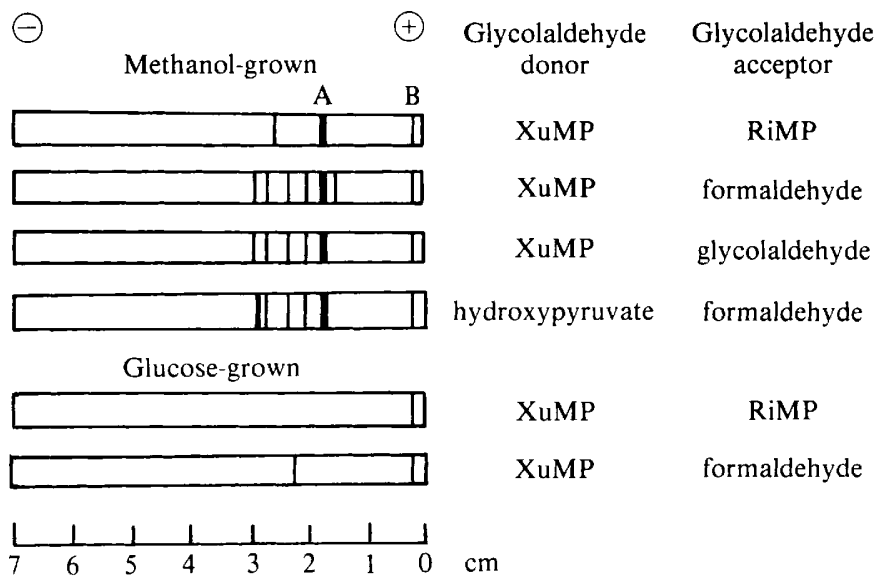

Fig. 3. Non-equilibrium pH gradient electrophoresis (NEPHGE) of crude cell-free extracts of glucosegrown and methanol-grown $C$. boidinii. Cell-free extract $(40-60 \mu \mathrm{l})$ was applied to the NEPHGE gels $\mathrm{pH} \mathrm{5-7}$ and run at $400 \mathrm{~V}$ for $3 \mathrm{~h}$ at $0^{\circ} \mathrm{C}$. Gels were then incubated in an activity stain mixture containing various combinations of glycolaldehyde donors and acceptors. See Methods for details. Band $\mathrm{A}$ is identified as DHA synthase and B may possibly be classical transketolase (see text).

activity-staining mixture in the presence of XuMP or hydroxypyruvate as donor substrates along with RiMP, formaldehyde or glycolaldehyde as acceptor substrates and also was only present in gels of methanol-grown cell extract (Fig. 3). The band was removed, extracted and submitted to SDS-polyacrylamide gel electrophoresis in order to obtain further confirmation of the subunit size. Using this procedure an estimated subunit molecular weight of 62500 was obtained.

\section{DISCUSSION}

Candida boidinii CBS 5777 when grown on methanol, ethanol or xylose synthesizes a classical transketolase of molecular weight $130000-142500$; there is no evidence that more than one enzyme is synthesized by the organism grown on these different substrates. Classical transketolases have previously been characterized from a variety of yeast species and their 
Table 7. Molecular weights and subunits of classical transketolase and DHA synthases from yeasts

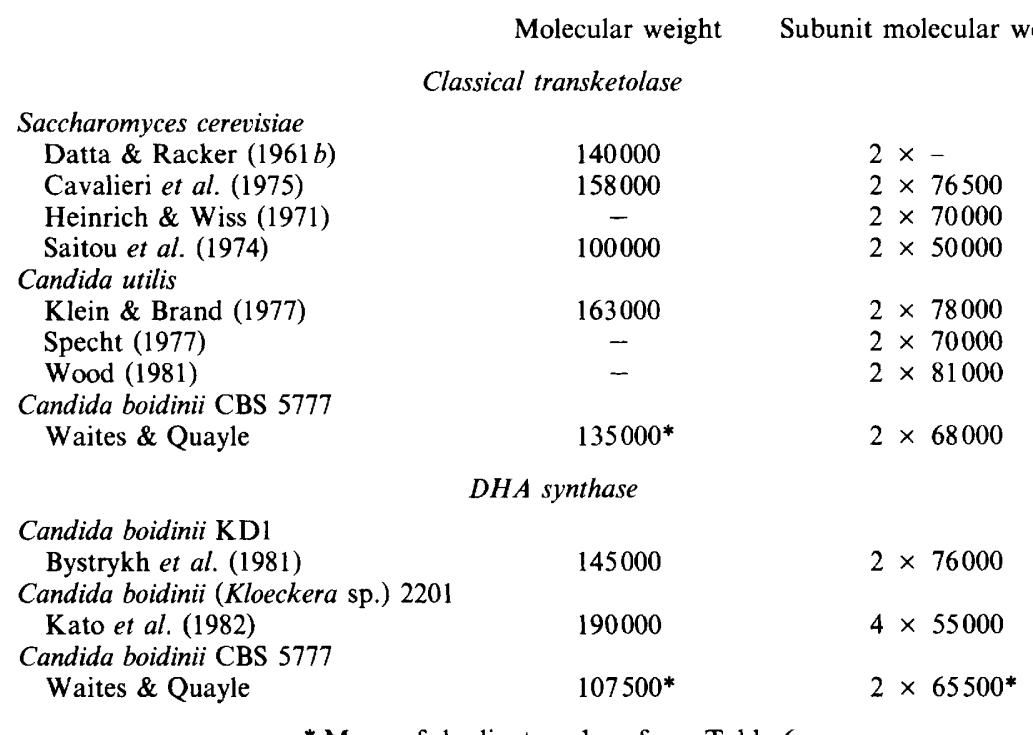

* Mean of duplicate values from Table 6.

molecular weights range from 100000 to 163000 (Table 7); they are dimeric proteins, as is the enzyme from methanol-grown $C$. boidinii CBS 5777. Classical transketolases, in general, do not exhibit strict specificity towards donors or acceptors of glycolyl groups. Efficient donors include XuMP, fructose 6-phosphate, sedoheptulose 7-phosphate and hydroxypyruvate; RiMP, erythrose 4-phosphate and GAP are efficient acceptors, while aldehydes, including formaldehyde, are very poor acceptors (Racker, 1961). No detailed examination has been made of the substrate specificity of the classical transketolase from C. boidinii CBS 5777. It is active towards the XuMP/RiMP couple but, under the assay conditions used, no reaction between XuMP and formaldehyde could be observed (Waites \& Quayle, 1981).

The DHA synthases from C. boidinii CBS 5777, C. boidinii 2201 (Kato et al., 1982) and $C$. boidinii KD1 (Bystrykh et al., 1981) show a similar lack of strict specificity towards the glycolyl donor as do classical transketolases. The best donor substrates for the enzymes from the first two organisms are XuMP $>$ hydroxypyruvate $>$ fructose 6-phosphate. The greatest difference between the DHA synthases from C. boidinii CBS 5777 and C. boidinii 2201 and the classical transketolases is the greater reactivity of the former two enzymes towards aldehydes as acceptors. In the case of the enzyme from strain CBS 5777, the relative activity towards donors is: glycolaldehyde $>$ erythrose 4-phosphate $>$ formaldehyde $>$ RiMP $>$ glyceraldehyde $>$ acetaldehyde. In the case of the enzyme from strain 2201, the following substrates were also tested and found to be good acceptors: butyraldehyde $>$ propionaldehyde $>$ heptaldehyde $>$ glycolaldehyde $>$ formaldehyde $>$ D-erythrose $>$ D-glucose $>$ D-ribose. These two enzymes therefore encompass a remarkable range of efficient glycolyl donors and acceptors. The enzyme from $C$. boidinii KD1 is reported to show activity only towards formaldehyde as acceptor (Bystrykh et al., 1981). Since RiMP is inactive as acceptor, presumably this enzyme displays no classical transketolase activity; this could have metabolic implications.

There are interesting differences in the molecular weights of the DHA synthases from $C$. boidinii CBS 5777, C. boidinii KD1 and C. boidinii 2201 : the first two enzymes have approximate molecular weights of 107500 and 145000 , respectively, and are dimeric, while the last enzyme has a molecular weight of 190000 and is tetrameric (Tables 6, 7 and 8). It is not known whether aggregation/disaggregation behaviour could explain these apparent differences, which are somewhat unexpected in three strains of the same species; multiple forms of classical transketolase or association of this enzyme with other proteins have frequently been observed (see Wood, 1981). 
Table 8. Summary of the properties of DHA synthases from different strains of Candida boidinii

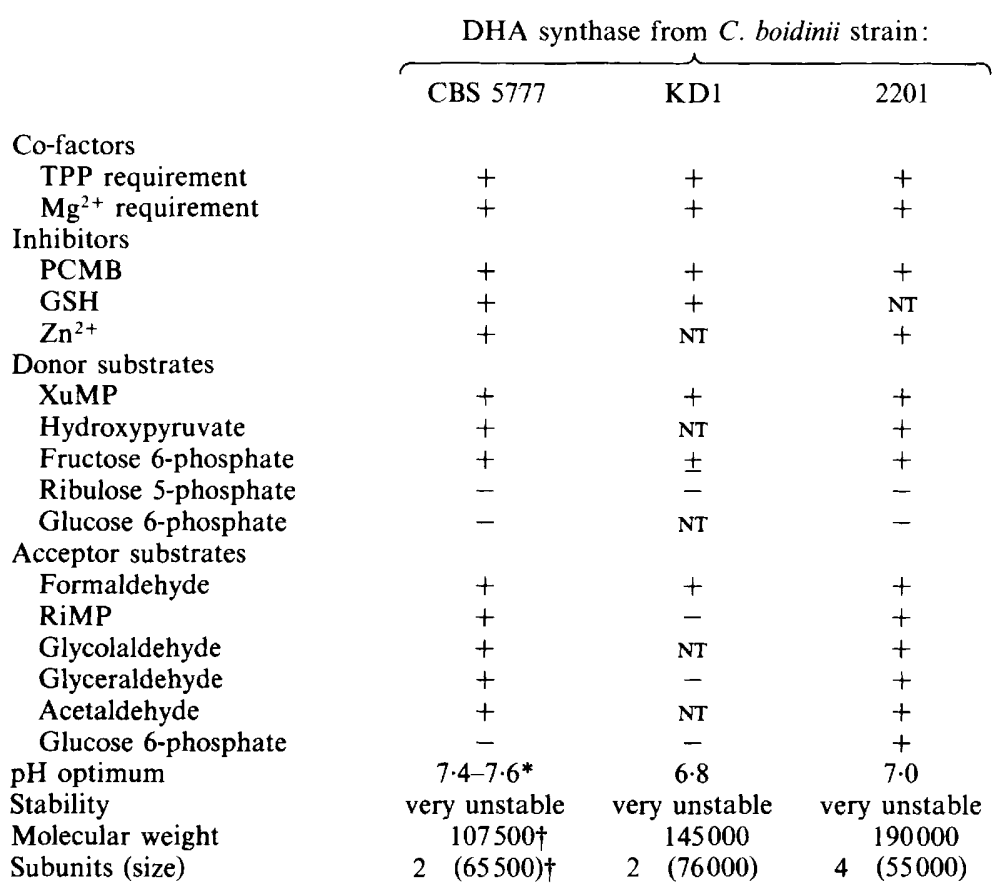

NT, Not tested; - , no activity.

* O'Connor \& Quayle (1980).

$\dagger$ Mean of duplicate values in Table 6 .

The DHA synthases purified from the three different sources all show a requirement for TPP and $\mathrm{Mg}^{2+}$ and are inhibited by thiol reagents. As with many classical transketolases, DHA synthase from CBS 5777 is inhibited by sulphate ions at concentrations in excess of $10 \mathrm{~mm}$. This fact needs to be borne in mind when using coupling enzymes suspended in ammonium sulphate solutions.

The question as to whether the high classical transketolase activity of DHA synthase plays any supplementary metabolic role in the pentose phosphate rearrangement phase of the XuMP cycle has been raised previously (Waites \& Quayle, 1981). In the absence of mutant data this question still remains open, although the apparent lack of classical transketolase activity of the DHA synthase from $C$. boidinii KD1 would eliminate such a possibility in this particular organism.

We thank Dr C. E. Furlong (Seattle, U.S.A.) for helpful discussions regarding procedures for activity staining of polyacrylamide gels and the Science and Engineering Research Council for support under grant number GR/A/65966.

\section{REFERENCES}

BySTRYKH, L. V., Sokolov, A. P. \& TRotSEnko, Y. A (1981). Purification and properties of dihydroxyacetone synthase from the methylotrophic yeast Candida boidinii. FEBS Letters 132, 324-328.

Cavalieri, S. W., Neet, K. E. \& Sable, H. Z. (1975). Enzymes of pentose biosynthesis. The quaternary structure and reacting form of transketolase from baker's yeast. Archives of Biochemistry and Biophysics 171, 527-532.
DAtTA, A. G. \& RACKer, E. (1961 $a$ ). Mechanism of action of transketolase. I. Properties of the crystalline yeast enzyme. Journal of Biological Chemistry 236, 617-623.

DATTA, A. G. \& RACKER, E. (1961b). Mechanism of action of transketolase. II. The substrate enzyme intermediate. Journal of Biological Chemistry 236, 624-628.

Eisenthal, R. \& CoRnish-Bowden, A. (1974). The 
direct linear plot. A new graphical procedure for estimating enzyme kinetic parameters. Biochemical Journal 139, 715-720.

Heinrich, C. P. \& Wiss, O. (1971). Subunit size of transketolase from baker's yeast. FEBS Letters 14, 251-253.

Kato, N., Nishizawa, T., Sakazawa, C., Tani, Y. \& YAMADA, H. (1979). Xylulose 5-phosphate dependent fixation of formaldehyde in a methanolutilizing yeast Kloeckera sp. no. 2201. Agricultural and Biological Chemistry 43, 2013-2015.

Kato, N., Higuchi, T., Sakazawa, C., Nishizawa, T., Tani, Y. \& Yamada, H. (1982). Purification and properties of a transketolase responsible for formaldehyde fixation in a methanol-utilizing yeast Candida boidinii (Kloeckera sp.) no. 2201. Biochimica et biophysica acta 715, 143-150.

KleIN, H. \& BRAND, K. (1977). Reinigung und Eigenschaften der Transketolase aus Candida utilis. Hoppe-Seyler's Zeitschrift für Physiologische Chemie 358, $1325-1337$.

LAEMMLI, U. K. (1970). Cleavage of structural proteins during the assembly of the head of bacteriophage $\mathrm{T} 4$. Nature, London 227, 680-685.

Lindley, N. D., Waites, M. J. \& QuaYle, J. R. (1981). Simultaneous assay of dihydroxyacetone synthase and transketolase in a methylotrophic yeast grown in continuous culture. A cautionary note. Journal of General Microbiology 126, 253-259.

Lück, H. (1963). Catalase. In Methods of Enzymatic Analysis, pp. 885-894. Edited by H. U. Bergmeyer. New York \& London: Academic Press.

O'Connor, M. L. \& Quayle, J. R. (1980). Pentose phosphate-dependent fixation of formaldehyde by methanol-grown Hansenula polymorpha and Candida boidinii. Journal of General Microbiology 120, 219225 .
O'Farrell, P. Z., Goodman, H. M. \& O'Farrell, P. H. (1977). High resolution two-dimensional electrophoresis of basic as well as acidic proteins. Cell 12, 1133-1142.

RACKER, E. (1961). Transketolase. In The Enzymes, vol. 5, pp. 397-406. Edited by P. D. Boyer, H. Lardy \& R. Myrbäck. New York \& London: Academic Press.

Saitou, S., Ozawa, T. \& Tomita, I. (1974). The purification and some properties of brewer's yeast apotransketolase. FEBS Letters 40, 114-118.

SPECHT, W. (1977). Molekulare und kinetische Eigenschaften einer aus Candida utilis isolierten Transketolase. Doctoral dissertation, Georg-August Universität zu Göttingen.

VAN DiJken, J. P., Otto, R. \& Harder, W. (1976). Growth of Hansenula polymorpha in a methanollimited chemostat. Physiological response due to involvement of methanol oxidase as a key enzyme in methanol metabolism. Archives of Microbiology 111, 137-144.

VAn DiJken, J. P., Harder, W., Beardsmore, A. J. \& QuAYle, J. R. (1978). Dihydroxyacetone: an intermediate in the assimilation of methanol by yeasts? FEMS Microbiology Letters 4, 97-102.

WaITES, M. J. \& QuAYLE, J. R. (1980). Dihydroxyacetone: a product of xylulose 5-phosphate-dependent fixation of formaldehyde by methanol-grown Candida boidinii. Journal of General Microbiology 118 , 321-327.

Waites, M. J. \& Quayle, J. R. (1981). The interrelationship between transketolase and dihydroxyacetone synthase activities in the methylotrophic yeast Candida boidinii. Journal of General Microbiology 124, 309-316.

WoOD, T. (1981). The preparation of transketolase free from D-ribulose-5-phosphate-3-epimerase. Biochimica et biophysica acta 659, 233-243. 